\title{
Antioxidant defense system during endometrial receptivity in the guinea pig: effect of ormeloxifene, a selective estrogen receptor modulator
}

\author{
A Makker, F W Bansode, V M L Srivastava ${ }^{1}$ and M M Singh \\ Division of Endocrinology, Central Drug Research Institute, Lucknow-226 001, India \\ ${ }^{1}$ Division of Parasitology, Central Drug Research Institute, Lucknow, India \\ (Requests for offprints should be addressed to M M Singh; Email: singhmm@rediffmail.com)
}

\begin{abstract}
The role of the antioxidant defense system during endometrial receptivity, a phenomenon crucial for implantation and decidualization, and the effect of ormeloxifene, a selective estrogen receptor modulator, were investigated in the guinea pig, a laboratory mammalian species with interstitial implantation and a long functional luteal phase during each estrous cycle. A sharp rise in the activity of superoxide dismutase (SOD) in both antimesometrial (AM) and mesometrial segments and peroxidase in the AM segment of the uterus was observed on the day of maximal endometrial receptivity. Pretreatment with ormeloxifene resulted in loss of endometrial responsiveness, as evidenced by inhibition of trauma-induced decidualization and the activity of ornithine decarboxylase, a marker of tissue growth and repair. This was associated with a decrease in SOD and estradiol dehydrogenase activities, with corresponding increases in estrone dehydrogenase activity and stimulation of uterine luminal epithelial cell height and a distension of the uterine and glandular lumen. A decrease in peroxidase activity was observed only in the AM segment of the uterus on the imminent
\end{abstract}

day of maximal endometrial receptivity. No effect on peripheral plasma progesterone concentration or surface ultrastructure was evident. These findings demonstrate that SOD plays an important role, with peroxidase having a supplementary role, in the first line of defense against superoxide anion radicals during the period of maximal endometrial receptivity in the guinea pig. Inhibition of endometrial receptivity and decidualization by ormeloxifene administered during the pre-receptive phase appears to be due to a depressed antioxidant defense system via dysregulation of redox-sensitive signaling, resulting in altered cellular toxicity due to increased superoxide radicals, and might contribute to the contraceptive action of ormeloxifene. This might be related to its estrogen antagonistic activity and/or decreased bioavailability of estradiol at a cellular level due to its increased metabolism to biologically less-active estrone via activation of estradiol-17 beta-hydroxysteroid dehydrogenase and suppression of estrone-17 beta-hydroxysteroid dehydrogenase.

Journal of Endocrinology (2006) 188, 121-134

\section{Introduction}

Aerobic metabolism is inextricably associated with the generation of reactive oxygen species (ROS). These species are extremely hazardous and so a complex system of tissue-/species-specific antioxidant defenses has evolved to meet this challenge (Droge 2002). Oxidative stress, an excessive production of ROS outstripping the antioxidant defense mechanism, has been implicated in several pathophysiological conditions (Fridovich 1978). However, oxidative stress might also serve important physiological functions in normal development by triggering differentiation pathways (Agarwal \& Laloraya 1979, Jauniaux et al. 2000).

A role of ROS and superoxide dismutase (SOD), an enzyme that scavenges superoxide radicals, in the regulation of endometrial (Narimoto et al. 1990, Sugino et al. 2001) and corpus luteum (Takiguchi et al. 2000) function has been suggested. $\mathrm{O}_{2}{ }^{--}$radicals have also been suggested to mediate increased vascular permeability, a non-genomic response of estrogen action, necessary for initiation of implantation and decidualization (Laloraya et al. 1989). A role has been demonstrated for ovarian steroids, primarily estrogen, in the modulation of infiltration and function of mononuclear phagocytes, which produce superoxide radicals/hydrogen peroxide and cause apoptosis and damage to endometrial cells (McMaster et al. 1992, Sugino et al. 2002) and up-regulation of SOD expression in monocytes isolated after pituitary down-regulation from young women recruited for in vitro fertilization (Strehlow et al. 2003). An exaggerated expression of SOD observed in patients with endometriosis and adenomyosis has also been 
related to the role of superoxide in infertility and/or miscarriage associated with these diseases (Ota et al. 1999a).

However, information on the precise role of the antioxidant defense system during endometrial receptivity, a phenomenon crucial for implantation and decidualization, is lacking. In addition, the effect of the selective estrogen receptor (ER) modulator (SERM) ormeloxifene (International Nonproprietary Name for centchroman) administered during the period preceding onset of endometrial receptivity on enzymes of the antioxidant defense system (see later Materials and Methods Section I) and uterine responsiveness to deciduogenic stimulus using uterine weight, histology, histomorphometry and ornithine decarboxylase (ODC) activity (a marker of tissue growth and repair) (Section II) as parameters has been investigated. The estrogen antagonistic profile of ormeloxifene (Section III) was evaluated in ovariectomized adult guinea pigs. The guinea pig, by virtue of its similarity to humans in having completely interstitial implantation and a long functional luteal phase during each estrous cycle (Motta \& Hutchinson 1991, Makker et al. 1994), offers a unique opportunity to undertake such studies requiring a large sample size and surgical interventions, which may not be feasible in humans. According to Guidice (1999), despite marked advances in our understanding of endometrial physiology, establishment of uterine receptivity remains a biological mystery. Since its better understanding is likely to help not only in a better outcome of the assisted conception programs, but might also serve as a potential target for contraception, it remains a pivotal area of research.

This study provides evidence for SOD being an important antioxidant enzyme, with peroxidase playing a facilitatory role, in protecting the uterus against oxidative damage during maximal endometrial receptivity in the guinea pig.

\section{Materials and Methods}

\section{Animals and treatment}

Adult female guinea pigs were treated s.c. with the vehicle (20\% ethanol in distilled water) or the SERM ormeloxifene $(10 \mathrm{mg} / \mathrm{kg}$ daily, s.c.; Makker \& Singh 1992, Singh 2001) on days 0-4 of the estrous cycle (day 0: first day of vaginal opening; Mehrotra \& Finn 1974). Procedures for breeding, housing and feeding of guinea pigs used in this study are the same as described in detail earlier (Makker et al. 1994). All animal studies were conducted in accordance with the principles and procedures outlined by the Institutional Ethical Committee.

\section{Chemicals and reagents}

Ormeloxifene synthesized at this institute (Saeed et al. 1990) was used. All chemicals were purchased from Sigma Chemical Company.

\section{Section I}

Antioxidant enzyme assays The animals were autopsied on days 1, 3 (pre-receptivity), 5 (maximum receptivity; Mitchell \& Garris 1978, Makker et al. 1994), 6 and 7 (post-receptivity) of the estrous cycle. Antimesometrial (AM) and mesometrial segments were separated by cutting along the entire lateral lengths of each uterine horn (Chen et al. 1989, Makker et al. 1994). Uterine segments from two or three animals of each treatment group were pooled and processed for enzyme analysis. Assays were repeated three to five times for each parameter. Tissue samples collected on the day of maximal endometrial receptivity were also fixed for histology, histochemistry and scanning electron microscopy (Singh et al. 1988).

All subsequent procedures were performed in a coldroom $\left(0-4{ }^{\circ} \mathrm{C}\right)$ unless otherwise specified. For enzyme assays, AM and mesometrial segments were homogenized $(5 \%, \mathrm{w} / \mathrm{v})$ in isotonic potassium chloride solution using an Ultra-Turrax blender for $10 \mathrm{~s}$ and centrifuged at $800 \mathrm{~g}$. Supernatants were recentrifuged at $9000 \mathrm{~g}$ for $30 \mathrm{~min}$ followed by ultracentrifugation (model M-60; International Equipment Company (IEC), Needham, MA USA) at $105000 \mathrm{~g}$ for $60 \mathrm{~min}$ at $0-4{ }^{\circ} \mathrm{C}$ to obtain the cytosolic fraction. Mitochondrial and microsomal pellets were suspended in $10 \mathrm{mM}$ Tris- $\mathrm{HCl}$ buffer $(\mathrm{pH} 7 \cdot 2$ ) containing $0.5 \mathrm{M} \mathrm{CaCl}_{2}$ (Lyttle \& DeSombre 1977), sonicated for $5 \mathrm{~s}$ on a cell disrupter (model W220F; Heat Systems, Ultrasonics Inc., Plainview, New York, USA) and centrifuged at $9000 \mathrm{~g}$ for $30 \mathrm{~min}$ to remove the membranous fraction. The endometrium has two types of SOD enzymes, the cytosolic or the copper-zinc SOD $(\mathrm{Cu}, \mathrm{Zn} \mathrm{SOD})$ located in the cytosol and the manganese SOD (Mn SOD) located in the mitochondria. Since the activity of only the cytosolic or $\mathrm{Cu}, \mathrm{Zn}$ SOD is modulated by ovarian steroids, while Mn SOD remains unaffected (Kaneko et al. 2001, Sugino et al. 2002), and since onset of endometrial receptivity as well as preparation and maintenance of the uterus for implantation and decidualization are hormone-dependent phenomena, changes in only the activity of cytosolic or $\mathrm{Cu}, \mathrm{Zn} \mathrm{SOD}$ were evaluated in the present study. $\mathrm{Cu}, \mathrm{Zn}$ SOD, catalase (CAT) and glucose-6-phosphate dehydrogenase (G-6-PDH) and microsomal peroxidase were assayed spectrophotometrically as described previously (Singh et al. 1996a). Glutathione reductase (GR) activity in cytosol was measured according to the method described by Racker (1955). Total protein content in cytosol and the microsomal fraction was measured colorimetrically (Lowry et al. 1951) using BSA (fraction V) as standard. Intra- and inter-assay variations were within normal limits.

Histochemistry For histochemical localization of peroxidase, the method of King et al. (1981) was followed with slight modifications. Uteri kept in ice-cold physiological saline were cut into $3-5 \mathrm{~mm}$ pieces, embedded and 
mounted in cryoform freezing medium (IEC) at $-20{ }^{\circ} \mathrm{C}$ in a cryostat chamber. Cross-sections $(5 \mu \mathrm{m})$ collected on silane-coated microscopic slides were stained with a solu-

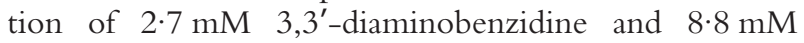
$\mathrm{H}_{2} \mathrm{O}_{2}$ in $0.1 \mathrm{M}$ citrate buffer, pH 5.6 at $20{ }^{\circ} \mathrm{C}$ for $45 \mathrm{~min}$ and lightly counterstained in $0 \cdot 1 \%$ methyl green before dehydration in ascending grades of ethanol. Adjacent sections were stained with hematoxylin and eosin. Due to non-availability of species-specific antibodies, similar studies on other enzymes of the antioxidant defense system could not be undertaken.

For histochemical localization of 17 beta-hydroxysteroid dehydrogenases (17 beta-HSD), the method of Schublinsky et al. (1976) was followed using estrone and estradiol- $17 \beta$ as substrates for type- 1 and type-2 17 beta-HSD respectively, with slight modifications. Briefly, the uteri were washed in ice-cold physiological saline, cut into small pieces and immediately soaked in a cold solution of dextran T40 (15\%) and DMSO (1.5\%) in Tris-maleate-Tyrode's buffer (TMB) $(\mathrm{pH} 7 \cdot 4)$, embedded and mounted in cryoform freezing medium. Cross-sections $(8 \mu \mathrm{m})$ were collected on silanecoated slides, thawed and immersed in Tris-maleateTyrode's buffer ( $\mathrm{pH} \quad 7 \cdot 4$ ) containing $5 \%$ polyvinyl pyrrolidine (PVP), 5\% DMSO and 4.3\% N,N-dimethyl formamide (DMF). Sections were then incubated in TMB ( $\mathrm{pH} 7 \cdot 4$ ) containing $6.1 \mathrm{mM}$ PVP, $2.5 \mathrm{mM}$ nitroblue tetrazolium chloride (NBT), $9.95 \mathrm{mM}$ cofactor (NADH for type-1 or NAD for type-2 17 beta-HSD) and $17 \mathrm{mM}$ estrone or estradiol-17 $\beta$ in DMF for 45 min (type-1) or $2 \mathrm{~h}$ (type-2) at $37^{\circ} \mathrm{C}$. Sections incubated in medium without the substrate served as respective controls. At termination of incubation, tissue sections were fixed in $10 \%$ formaldehyde and 90\% TMB, counterstained with $1 \%$ aqueous Saffranin $\mathrm{O}$ and mounted in glycerin.

Surface ultrastructure Uteri isolated from vehicle control and ormeloxifene pretreated guinea pigs on day 5 (i.e. the day of maximal receptivity) of the estrous cycle were fixed in freshly prepared $0 \cdot 1 \mathrm{M}$ sodium cacodylate buffer $\left(0-4{ }^{\circ} \mathrm{C}, \mathrm{pH} 7 \cdot 3 \pm 0 \cdot 1\right)$ containing $3 \%$ glutaraldehyde and $2 \%$ paraformaldehyde, processed, and photographed on a Philips 515 Scanning electron microscope (Makker et al. 1994).

\section{Section II}

Endometrial receptivity determination Relative endometrial receptivity was evaluated by the extent of decidual response following complete scissor-cut traumatization (Garris 1984) along the entire AM length of the uterus between 0900 and $1100 \mathrm{~h}$ on day 5 of the estrous cycle (Mehrotra \& Finn 1974, Makker et al. 1994) under light ether anesthesia. Care was taken not to disturb the contralateral control uterine horn. Pertinently, the AM segment of the uterus is the first to acquire receptivity, and traumatization along this side during only the brief period of maximal endometrial receptivity to blastocyst signal(s) elicits an optimal decidual response (Weitlauf 1994). Animals were autopsied on days 5 (day of maximal endometrial receptivity) (Mitchell \& Garris 1978), 8, 10 and 12 of the estrous cycle (i.e. 0, 3, 5 and 7 days post-traumatization). In ormeloxifene $(10 \mathrm{mg} / \mathrm{kg}$ daily, s.c., days $0-4$ of the estrous cycle) pretreated groups, animals were autopsied only on days 5 (i.e. imminent day of endometrial receptivity) and 12 (i.e. 7 days posttraumatization, when the optimal decidual response is evident in vehicle-treated females). Decidual response was measured as percent weight gain, histology, histomorphometry and ODC activity, a marker of tissue growth and repair (Barkai \& Kraicer 1978), of the traumatized uterine horn over the contralateral non-traumatized uterine horn. About $2 \mathrm{ml}$ blood samples collected in heparinized tubes between 0900 and $1100 \mathrm{~h}$ from each animal at autopsy were centrifuged and plasma was stored at $-20{ }^{\circ} \mathrm{C}$ until analyzed for estradiol and progesterone.

Histology and histomorphometry Middle segments of traumatized and non-traumatized uteri were fixed in fresh Bouin's fixative. Transverse sections $(5 \mu \mathrm{m})$ were stained with hematoxylin and eosin. Photomicrographs of sections were obtained using a Leica DC 300 camera and Leica IM50 Image Acquisition software fitted to a Leica DMLB microscope. Histomorphometry measurements including total uterine area, endometrial area, endometrial thickness, luminal epithelial area, luminal and glandular epithelial cell height and area of the lumen were carried out using Leica Qwin-Semiautomatic Image Analysis software and the differences were represented as percent of corresponding control group.

ODC activity AM and mesometrial segments from traumatized and non-traumatized uterine horns from each animal were homogenized in ice-cold buffer containing $50 \mathrm{mM}$ Tris- $\mathrm{HCl}(\mathrm{pH} 7 \cdot 4), 0 \cdot 25 \mathrm{M}$ sucrose and $0 \cdot 1 \mathrm{mM}$ EDTA to achieve a final concentration of $100 \mathrm{mg}$ tissue/ $\mathrm{ml}$. Homogenates were centrifuged at $12000 \mathrm{~g}$ for $10 \mathrm{~min}$ at $0-4{ }^{\circ} \mathrm{C}$ and the supernatants were stored at $-70{ }^{\circ} \mathrm{C}$ and assayed for ODC activity (Kaye et al. 1971).

Peripheral plasma estradiol and progesterone concentration Blood plasma samples were analyzed for estradiol and progesterone by RIA (Singh et al. 1988) using methods and kits supplied by WHO, Geneva under their Matched Reagent Program. Intra- and inter-assay variations were within normal limits.

\section{Section III}

\section{Estrogen antagonistic activity of ormeloxifene}

Adult female guinea pigs bilaterally ovariectomized and given a post-operative rest for 15 days were treated with 
estradiol-17 $\beta$ (5 $\mu \mathrm{g} /$ day, s.c.; Mehrotra \& Finn 1974) for 1,2 or 3 consecutive days or estradiol-17 $\beta$ together with ormeloxifene (10 mg/kg per day, s.c.) for 3 days. Animals of the control group received the vehicle(s) alone in a similar manner. Animals were autopsied $24 \mathrm{~h}$ after the last treatment and uteri were dissected out, weighed, cut into AM and mesometrial segments and processed for ODC estimation (Kaye et al. 1971). Vaginal opening of each animal was also checked at autopsy.

\section{Statistical analysis}

Data are represented as means \pm S.E.M. The means of relevant groups were compared by three-way ANOVA. In the case of peripheral plasma estradiol and progesterone concentrations, two-way ANOVA was used. Multiple comparisons were done by the Newman-Keuls test.

\section{Results}

\section{Antioxidant enzymes}

SOD SOD activity exhibited a marked increase on the day of maximal endometrial receptivity in both AM $(P<0 \cdot 05$, vs days 1 or 3$)$ and mesometrial $(P<0 \cdot 05$, vs day 3) segments of the uterus (Fig. 1A). This was followed by gradual decline on days 6 (AM: $P<0 \cdot 05$; mesometrial: $26 \%$, statistically not significant, vs corresponding vehicle control group) and 7 (AM: $P<0 \cdot 01$, vs days 5 or 6 ; mesometrial: $P<0 \cdot 05$, vs day 5$)$ to reach levels comparable with those on day 1 of the cycle. Ormeloxifene $(10 \mathrm{mg} /$ $\mathrm{kg}$, s.c.) treatment inhibited endometrial receptivityassociated increase in SOD activity in both AM $(P<0 \cdot 01)$ and mesometrial $(P<0 \cdot 05)$ segments, resulting in an almost unaltered state of enzyme activity between days 3 and 7 of the cycle.

Peroxidase In vehicle control females, peroxidase activity exhibited a marked $(P<0 \cdot 01$, vs days 1 and 3$)$ increase on the AM side of the uterus on the day of maximal endometrial receptivity (Fig. 1B). The activity was also significantly higher $(P<0 \cdot 01)$ on the AM than the mesometrial side of the uterus. Ormeloxifene pretreatment increased overall activity of the enzyme on days 1 (not significant) and $3(P<0 \cdot 05)$ of the estrous cycle as compared with the corresponding vehicle control animals. A significant decrease $(P<0 \cdot 01)$ in its activity was observed on the AM side of the uterus on day 5 , reaching levels even lower $(P<0 \cdot 05)$ than that observed in the AM segment of the uterus in control guinea pigs. In the mesometrial segment, in comparison, while an apparent decrease in activity was also evident on day 5 (vs corresponding days 1 and 3), the level of activity was always significantly (day 3: $P<0 \cdot 05$; days 1,5 and 6: $P<0 \cdot 01$ ) or not significantly (day 7 ) higher than the corresponding controls.
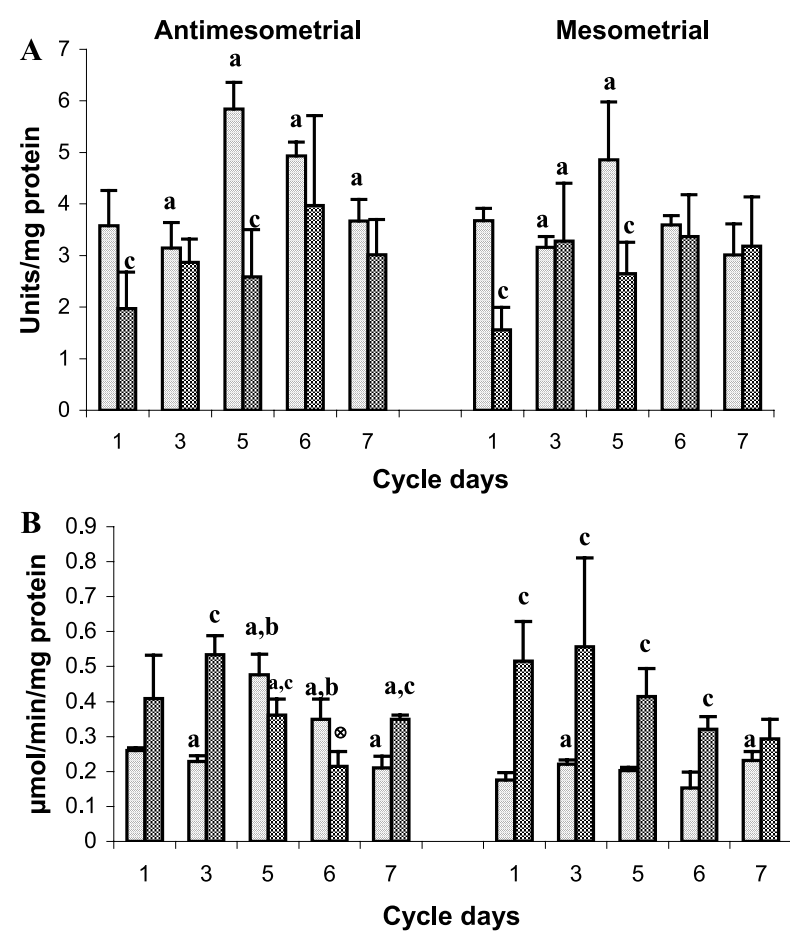

Figure 1 Changes in SOD (A) and peroxidase (B) activity in AM and mesometrial segments of the uterus in relation to endometrial receptivity in guinea pigs treated with vehicle (light bars) or ormeloxifene (dark bars) on days $0-4$ of the estrous cycle. Note sharp rise in SOD activity in both AM and mesometrial segments on the day of maximal endometrial receptivity in the control group. Increased peroxidase activity was found only in the AM segment. Ormeloxifene pretreatment was associated with a significant decrease in SOD in both the segments. Values represent mean of 3-5 observations in each group. Vertical bars indicate S.E.M. ${ }^{a} P<0 \cdot 05$, vs corresponding preceding day of cycle; ${ }^{\mathrm{b}} P<0 \cdot 05$, vs corresponding mesometrial segment of the uterus; ${ }^{\mathrm{c}} P<0 \cdot 05$, vs corresponding vehicle control group. All other relevant comparisons were statistically not significant. For reasons of clarity, the level of significance in the figure has been limited to $P<0 \cdot 05$. Higher level of significance, wherever applicable, has been shown in the text. [Symbol $\otimes]:$ a, b, c.

Histochemically, in animals of the vehicle control group, intense peroxidase staining was observed in uterine luminal and glandular epithelium and blood vessels on day 1 of the cycle, which increased initially in the mesometrial side on day 3 , followed by a marked increase along the AM side on the day of maximal endometrial receptivity (day 5 of the estrous cycle; Fig. 2A (arrow)). The activity spread to almost the entire endometrial stroma with edema along the AM side by day 6 and decreased during the post-receptive period on day 7 of the cycle. Ormeloxifene treatment on days $0-4$ of the estrous cycle decreased peroxidase activity in the AM as well as mesometrial stroma. Peroxidase activity on day 5 of the cycle was localized in subepithelial stroma and blood vessels and the expression was almost comparable with that observed on day 3 of the cycle in vehicle control 

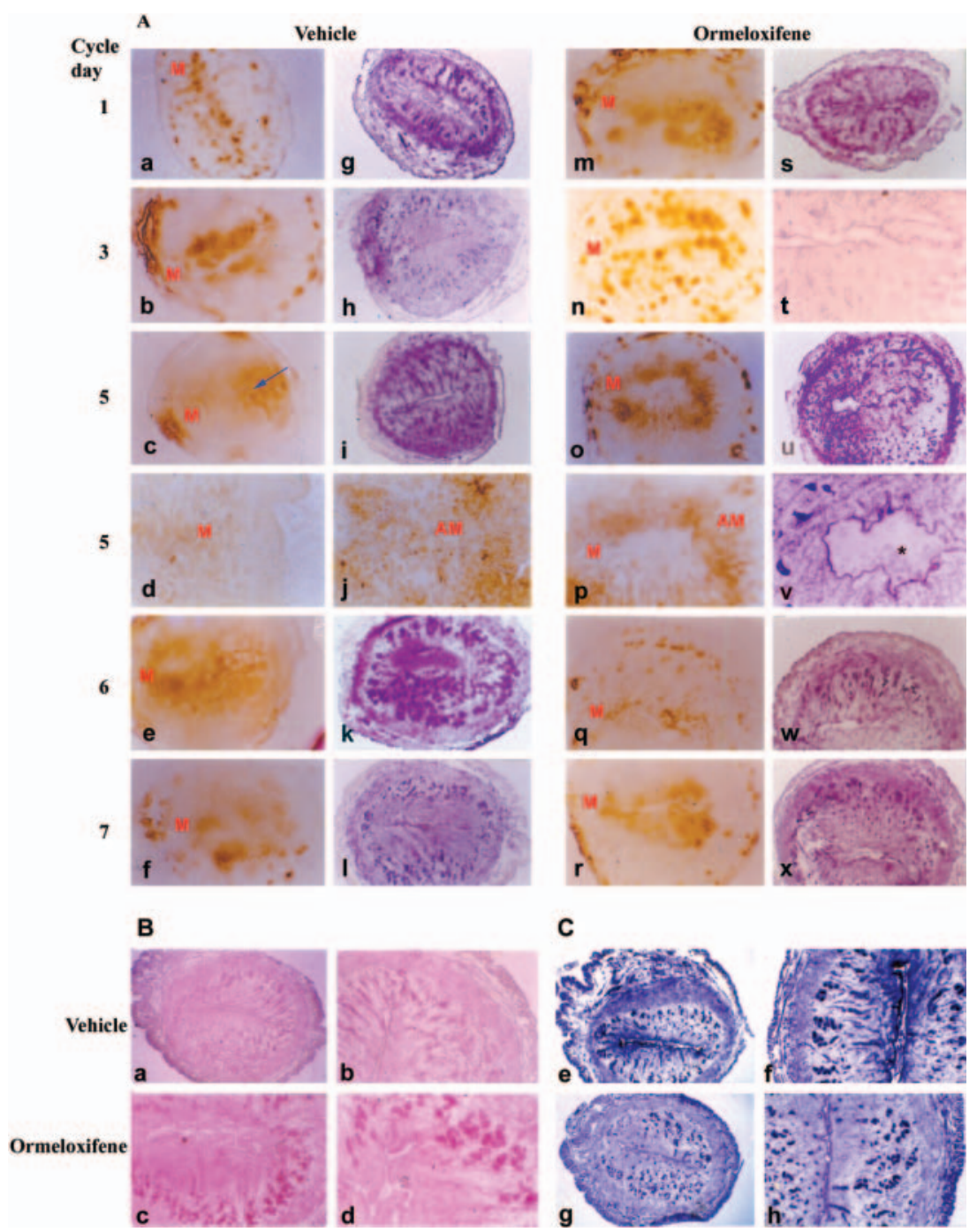

Figure 2 (A) Histochemical localization of peroxidase activity in the uterus of vehicle $(a-f)$ and ormeloxifene $(m-r)$ pretreated guinea pigs. Adjacent sections in each treatment group ( $\mathrm{g}-\mathrm{I}$ and $\mathrm{s}-\mathrm{x}$ respectively) have been stained with hematoxylin and eosin. Note marked increase in peroxidase staining along the AM side on the day of maximal endometrial receptivity (arrow). In ormeloxifene pretreated females, the enzyme activity on day 5 of the cycle was localized in subepithelial stroma and blood vessels and the expression was almost comparable with that observed on day 3 of the cycle in the control group. There was also marked distention of the uterine lumen $\left(^{*}\right)$. M: mesometrial. $\times 50$, except $d, j, p$ and $v: \times 100$. $(B, C)$ Histochemical localization of estradiol $(B)$ and estrone $(C)$ dehydrogenases in uteri of vehicle $(a, b$ and $e, f)$ and ormeloxifene pretreated $(c, d$ and g, h) guinea pigs on the day of maximal endometrial receptivity. Note increase in activity of estradiol dehydrogenase $(c, d)$ and inhibition in estrone dehydrogenase $(g, h)$ following ormeloxifene treatment. a, c, e, g: $\times 50 ; b, d, f, h: \times 100$.

guinea pigs. The activity on days 6 and 7 showed further decrease and the AM edema observed in control guinea pigs on day 6 of the cycle was also absent in ormeloxifenetreated females.

CAT, GR and G-6-PDH The activity of these enzymes, although high during the entire pre-implantation period, did not exhibit any alteration in relation to the period of maximal endometrial receptivity or ormeloxifene treatment.

\section{7 beta-HSDs}

Estradiol-17 beta-HSD Histochemical localization of estradiol-17 beta-HSD in vehicle control guinea pigs on 


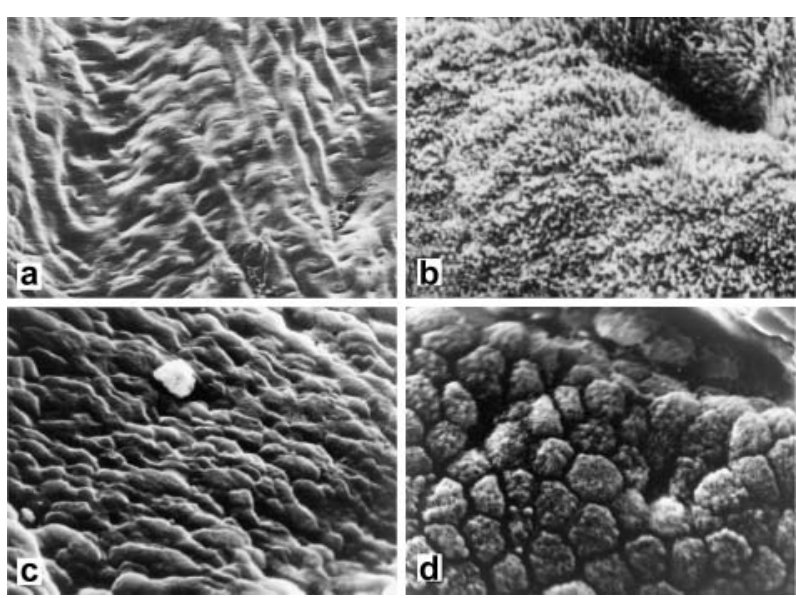

Figure 3 Scanning electron micrographs of uteri on the day of maximal endometrial receptivity in guinea pigs treated with vehicle $(\mathrm{a}, \mathrm{b})$ or ormeloxifene $(\mathrm{c}, \mathrm{d})$ on days $0-4$ of the estrous cycle. Note the uniformly undulated endometrial surface covered with a thick carpet of short microvilli with numerous openings of glands in vehicle control animals. Short microvilli with clear demarcation of cell boundaries are observed in females pretreated with ormeloxifene. a, c: $\times 1000, \mathrm{~b}, \mathrm{~d}: \times 3000$ (approx.).

the day of maximal endometrial receptivity showed positive enzyme activity in uterine luminal and glandular epithelium, subepithelial AM stroma, blood vessels and myometrium (Fig. 2B). Ormeloxifene treatment markedly increased enzyme activity in all segments of the uterus, particularly endometrial stroma and luminal and glandular epithelium.
Estrone-17 beta-HSD Intense staining of estrone-17 beta-HSD was observed in uterine luminal and glandular epithelium, subepithelial AM stroma and muscularis region on the day of maximal endometrial receptivity. Ormeloxifene treatment produced a marked decrease in enzyme activity in AM stroma, luminal epithelium and myometrium (Fig. 2C).

\section{Surface ultrastructure}

Ultrastructurally, the entire endometrial surface on the day of maximal endometrial receptivity in vehicle control animals was uniformly undulated with numerous openings of endometrial glands. At higher magnification, both AM and mesometrial surfaces were covered with a thick carpet of short microvilli and there was no apparent difference in their surface ultrastructure. Cell boundaries were not visible and pinopods and cilia were totally absent (Fig. 3). In females pretreated with ormeloxifene, uterine luminal epithelium showed the presence of short microvilli with clear demarcation of cell boundaries.

\section{Endometrial receptivity and decidual response}

Uterine weight, histology and histomorphometry The uterine lumen on the day of maximal endometrial receptivity in vehicle control females (Fig. 4A) was lined with cuboidal epithelium and the stroma consisted primarily of fibroblast-type cells. Some edema was apparent on the AM side. Glands were prominent along the mesometrial and lateral sides. Ormeloxifene pretreatment inhibited uterine weight $(\sim 27 \%$; statistically not

Table 1 Effect of ormeloxifene pretreatment on unilateral trauma-induced uterine decidualization in cyclic guinea pigs

\begin{tabular}{|c|c|c|c|c|c|c|c|}
\hline \multirow[b]{3}{*}{$\begin{array}{l}\text { Day post- } \\
\text { traumatization }\end{array}$} & \multicolumn{7}{|c|}{ Uterine weight (mg) } \\
\hline & \multicolumn{3}{|l|}{ Vehicle } & \multicolumn{4}{|l|}{ Ormeloxifene $^{a}$} \\
\hline & $\begin{array}{l}\text { Non-traumatized } \\
\text { horn }\end{array}$ & $\begin{array}{l}\text { Traumatized } \\
\text { horn }\end{array}$ & $\begin{array}{l}\text { Percent } \\
\text { gain }^{\mathrm{b}}\end{array}$ & $\begin{array}{l}\text { Non-traumatized } \\
\text { horn }\end{array}$ & $\begin{array}{l}\text { Traumatized } \\
\text { horn }\end{array}$ & $\begin{array}{l}\text { Percent } \\
\text { gain }^{\text {b }}\end{array}$ & $\begin{array}{l}\text { Percent } \\
\text { inhibition }^{\mathrm{c}}\end{array}$ \\
\hline \multicolumn{8}{|l|}{$\begin{array}{l}\text { Day of } \\
\text { estrous } \\
\text { cycle }\end{array}$} \\
\hline 0 & $340 \pm 17$ & & & $256 \pm 26$ & & & \\
\hline 8 & $314 \pm 40$ & $623 \pm 73^{\mathrm{e}, \mathrm{g}}$ & $105 \pm 21$ & & & & \\
\hline 10 & $257 \pm 18^{f}$ & $1435 \pm 128^{\mathrm{e}, \mathrm{g}, \mathrm{h}}$ & $468 \pm 63$ & & & & \\
\hline 12 & $231 \pm 15^{\mathrm{g}}$ & $2117 \pm 120^{\mathrm{e}, \mathrm{g}, \mathrm{h}}$ & $847 \pm 101$ & $298 \pm 5$ & $393 \pm 12^{\mathrm{d}, \mathrm{g}, \mathrm{l}}$ & $32 \pm 3$ & $82 \pm 1$ \\
\hline
\end{tabular}

Values are means \pm S.E.M. 5-6 animals per group.

a $10 \mathrm{mg} / \mathrm{kg}$ per day, s.c., days $0-4$ of estrous cycle.

${ }^{b}$ Percent of corresponding non-traumatized uterine horn.

'Percent of corresponding traumatized uterine horn of vehicle control group.

d $P<0 \cdot 05$, e $P<0 \cdot 01$; vs corresponding non-traumatized uterine horn.

${ }^{\mathrm{f}} P<0 \cdot 05,{ }^{\mathrm{g} P} P<0.01$; vs corresponding non-traumatized uterine horn on day 5 of estrous cycle.

${ }^{\mathrm{h}} \mathrm{P}<0 \cdot 01$; vs corresponding preceding value.

I $P<0 \cdot 01$; vs corresponding vehicle control group.

All other relevant comparisons were statistically not signficant.

Blank cells indicate data not available. 
significant; Table 1) and receptivity on day 5 of the cycle. This was associated with marked distension of the uterine lumen $(210 \%)$, increase in luminal epithelial cell height $(233 \%)$ and decrease in endometrial area $(26 \%)$ and thickness (35\%, Table 2). There was, however, no effect on glandular epithelium (Table 2), except that the glandular lumen also appeared highly distended with leukocytic infiltration (Fig. 4A).

Scissor-cut trauma along the AM side of the uterus on day 5 of the estrous cycle in vehicle control females induced marked weight gain $(P<0 \cdot 01)$ of the traumatized

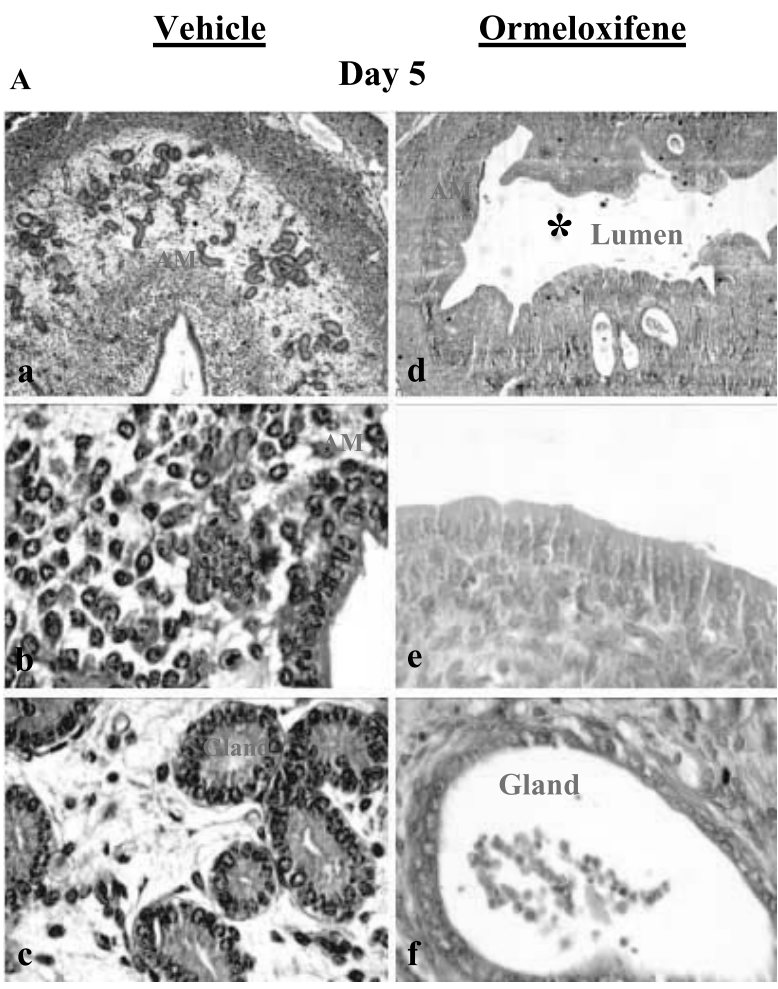

B

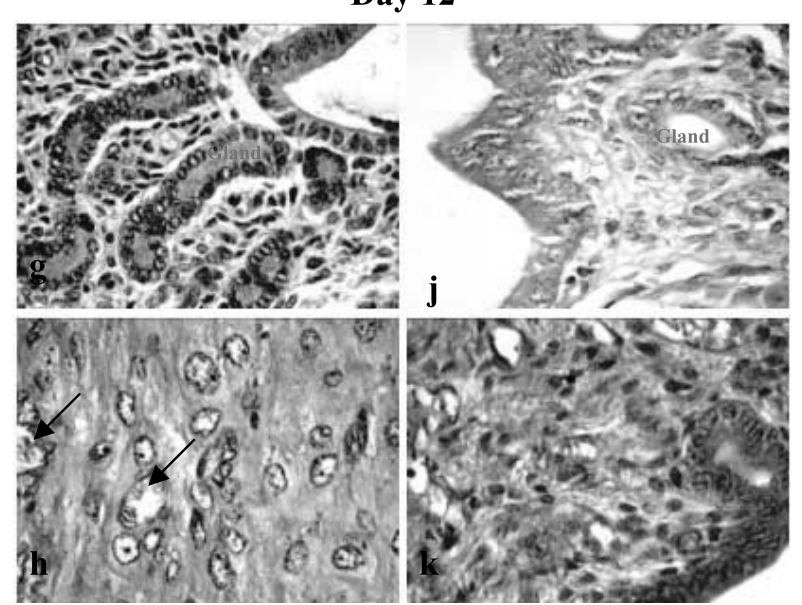

uterine horn (Table 1). Maximum uterine weight gain of $847+101 \%(P<0 \cdot 01)$ and increase in total uterine $(652 \%)$ and endometrial (1328\%) area was achieved 7 days after traumatization (Tables 1 and 2). Non-traumatized uterine horn, in comparison, exhibited a significant decrease in weight on days $10(P<0 \cdot 05)$ and $12(P<0 \cdot 01)$ of the cycle. The histological picture 3 days after traumatization (i.e. on day 8 of the estrous cycle) showed initiation of a decidual reaction along the periphery on the AM side. On day 5 post-trauma, an increase in the number of differentiated decidual cells was evident. On day 12 of the cycle (i.e. 7 days post-trauma), large numbers of decidual cells and mitotic figures were present on both the AM and mesometrial sides and demarcation between these segments was less distinct, except for a small zone of endometrial glands along the mesometrial side (Fig. 4B).

In ormeloxifene pretreated females, there was no evidence of a decidual response following unilateral traumatization and weight gain of the traumatized uterine horn 7 days post-traumatization was only $32 \pm 3 \%(P \leq 0 \cdot 05$, vs corresponding non-traumatized uterine horn), which was markedly lower than that of the traumatized horns of the vehicle control group $(P<0 \cdot 01)$. A comparison between uterine weight of the traumatized horn in the vehicle control and ormeloxifene pretreated groups shows an inhibition of $82 \pm 1 \%$. While total uterine area and endometrial thickness, too, remained almost unaltered, an increase in uterine luminal epithelial cell height (90\%) and marked distention (1689\%) of the uterine lumen was observed in non-traumatized uterine horns of ormeloxifene pretreated females (Table 2). There was, however, no significant change in weight of the non-traumatized uterine horn between days 5 and 12 of the estrous cycle in ormeloxifene pretreated animals. Histologically, the uterine luminal epithelium in ormeloxifene pretreated animals was tall columnar and the glands appeared highly distended. Stroma was compact and fibroblastic and

Figure 4 (A) Transverse sections of guinea pig uteri pretreated with vehicle $(\mathrm{a}-\mathrm{c})$ or ormeloxifene $(\mathrm{d}-\mathrm{f})$ on days $0-4$ of the estrous cycle and autopsied on day 5 of the cycle. Note cuboidal luminal epithelium with basal nuclei, well-developed endometrial glands and predecidual edematous subepithelial AM stroma in vehicle control females. In ormeloxifene pretreated females, distention of the uterine lumen $\left({ }^{*}\right)$ lined with tall columnar epithelium, and few glands with a wide lumen are observed. a, d: $\times 50 ; b, c, e, f: \times 100$. (B) Transverse sections of uterus of guinea pigs pretreated with vehicle $(g, h)$ or ormeloxifene $(j, k)$ on days $0-4$ of the estrous cycle. Unilateral scissor-cut trauma was applied on day 5 and females were autopsied 7 days thereafter, i.e. on day 12 of the cycle. Note compactly arranged decidual cells with large nuclei and increased vasculature (arrows) in traumatized uterine horn in vehicle control females (h), but lack of decidual response in ormeloxifene pretreated females $(k)$. The endometrial picture in the non-traumatized uterine horn of vehicle $(\mathrm{g})$ and ormeloxifene pretreated (j) females was almost comparable with the corresponding pictures on day 5 of the cycle. $\mathrm{g}, \mathrm{j}: \times 50$; h, k: $\times 100$. 
Table 2 Histomorphometry analysis of guinea pig uteri: effect of ormeloxifene pretreatment and/or unilateral scissor-cut traumatization

\begin{tabular}{|c|c|c|c|c|c|c|c|}
\hline \multirow[b]{3}{*}{$\begin{array}{l}\text { Day } 5 \text { of estrous cycle } \\
\text { Day } 12 \text { of estrous cycle }\end{array}$} & \multirow{2}{*}{$\begin{array}{l}\text { Uterus } \\
\left(\text { total area }{ }^{\mathrm{a}}\right)\end{array}$} & \multicolumn{2}{|c|}{ Endometrium } & \multicolumn{2}{|c|}{ Luminal epithelium } & \multirow{2}{*}{$\begin{array}{l}\text { Glandular epithelium } \\
\text { (cell height }^{\text {b }} \text { ) }\end{array}$} & \multirow{2}{*}{$\begin{array}{l}\text { Uterine lumen } \\
\left(\text { total } \text { area }^{\mathrm{a}}\right)\end{array}$} \\
\hline & & 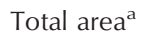 & Thickness $^{b}$ & Total area ${ }^{a}$ & Cell height ${ }^{b}$ & & \\
\hline & $\begin{array}{l}+27 \%^{\mathrm{c}} \\
+652 \%^{\mathrm{d}} \\
+7 \%^{\mathrm{c}} \\
-5 \%^{\mathrm{f}}\end{array}$ & $\begin{array}{l}-26 \%{ }^{\mathrm{c}} \\
+1328 \%^{\mathrm{d}} \\
-20 \%^{\mathrm{e}} \\
+102 \%^{\mathrm{f}}\end{array}$ & $-35 \%^{\mathrm{c}}$ & $+406 \%^{\mathrm{c}}$ & $+233 \%^{\mathrm{c}}$ & $+0.9 \%$ & $+210 \%^{\mathrm{c}}$ \\
\hline
\end{tabular}

Measured as ${ }^{\mathrm{a}} \mu \mathrm{m}^{2} ;{ }^{\mathrm{b}} \mu \mathrm{m}$.

Values represent percent change (+: increase; - : decrease) of the mean values of at least three measurements.

${ }^{\mathrm{c}}$ Ormeloxifene pretreated vs vehicle control group on day 5 of cycle, i.e. day of maximal endometrial receptivity.

${ }^{\mathrm{d}}$ Traumatized vs non-traumatized uterine horn of vehicle control group on day 12 of cycle, i.e. $96 \mathrm{~h}$ post-traumatization.

'Traumatized vs non-traumatized uterine horn of ormeloxifene pretreated group on day 12 of cycle, i.e. $96 \mathrm{~h}$ post-traumatization.

${ }^{\mathrm{f}}$ Non-raumatized uterine horm of ormeloxifene pretreated vs non-traumatized uterine horn of vehicle control group on day 12 of cycle.

Blank cells indicate information not available due to almost complete obliteration of uterine lumen $96 \mathrm{~h}$ after traumatization in vehicle control group.

decidual cells were completely absent. No difference was observed between traumatized and non-traumatized uteri in ormeloxifene-treated guinea pigs (Fig. 4B).

ODC The ODC activity on day 5 of the estrous cycle in vehicle control guinea pigs was significantly more $(P<0 \cdot 05)$ in the AM than the mesometrial segment of the uterus. The activity in the AM segment also elicited a marked increase with advancing decidualization following traumatization to reach peak levels (561\% of corresponding day 5 concentration) on day 12 of the estrous cycle, i.e. 7 days post-traumatization. The enzyme activity on days 8,10 and 12 was also significantly more when compared with that on day 5 of the cycle $(P<0 \cdot 01)$ or with that in the corresponding mesometrial segment (days 8 or 12: $P<0 \cdot 01$, day 10: $P<0 \cdot 05$ ) or with the AM segment of non-traumatized uterine horns (days 8,10 or 12: $P<0 \cdot 01$; Table 3). Ormeloxifene treatment on days $0-4$ of the estrous cycle significantly $(38 \%, P<0 \cdot 05)$ inhibited ODC activity in the AM segment of the uterus on day 5 of the cycle. A marked inhibition in enzyme activity was also observed 7 days post-traumatization and the levels were significantly lower in the AM segment of both traumatized $(P<0 \cdot 01)$ and non-traumatized $(P<0 \cdot 05)$ uterine horns and in the mesometrial segments $(P<0 \cdot 01)$ of non-traumatized uterine horns when compared with the corresponding vehicle control group. The enzyme activity in mesometrial segments of non-traumatized uterine horns was also markedly lower $(79 \%, P<0 \cdot 01)$ when compared with the corresponding day 5 concentration.

Table 3 Effect of ormeloxifene pretreatment on uterine ornithine decarboxylase activity during maximal endometrial receptivity and induced decidualization in cyclic guinea pigs

Ornithine decarboxylase activity (pmol $\mathrm{CO}_{2} / \mathrm{h} / \mathrm{mg}$ protein)

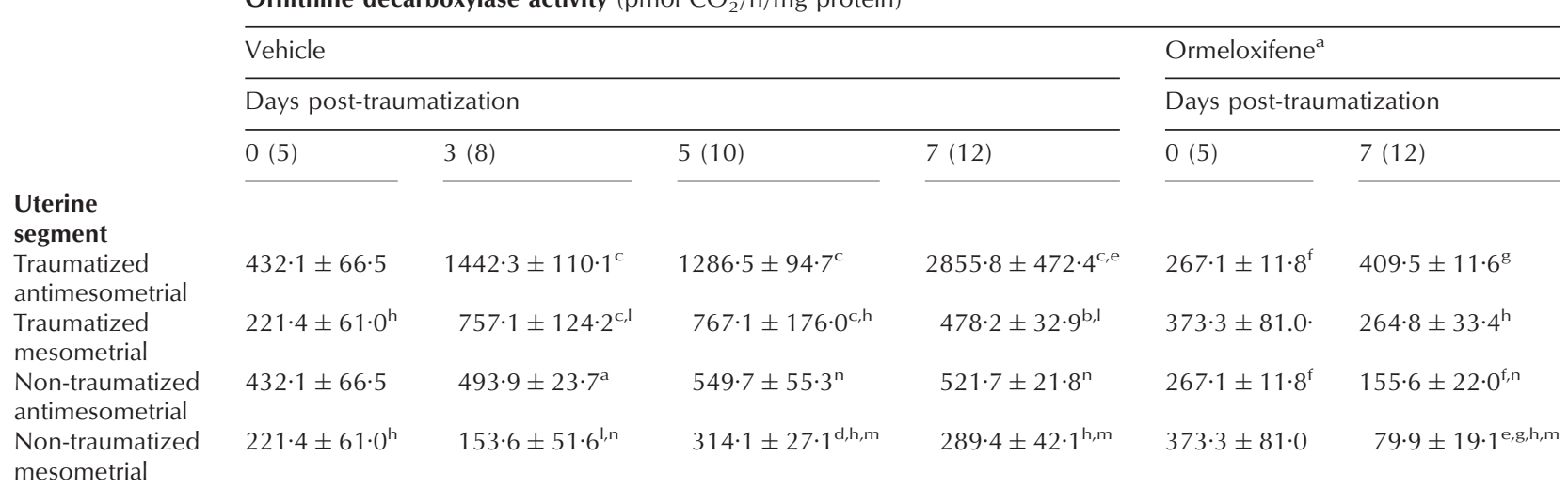

Day 0 represents the day of traumatization, i.e. day 5 of estrous cycle.

Values are means \pm S.E.M. of six observations per group. Values in parenthesis indicate corresponding day of estrous cycle.

${ }^{\mathrm{a}} 10 \mathrm{mg} / \mathrm{kg} /$ day, s.c., days $0-4$ of estrous cycle; ${ }^{b} P<0 \cdot 05,{ }^{\mathrm{c}} P<0 \cdot 01$; vs corresponding concentration on day 5 of cycle.

$\mathrm{d} P<0.05$, e $P<0.01$; vs corresponding proceeding day value; ${ }^{\mathrm{f}} P<0.05, \mathrm{~g} P<0.01$; vs corresponding vehicle control group.

${ }^{\mathrm{h}} \mathrm{P}<0 \cdot 05,{ }^{\mathrm{P}} \mathrm{P}<0 \cdot 01$; vs corresponding antimesometrial segment; ${ }^{\mathrm{m}} \mathrm{P}<0 \cdot 05,{ }^{\mathrm{n}} \mathrm{P}<0 \cdot 01$; vs corresponding segment of traumatized horn.

All other relevant comparisons were statistically not signficant. 

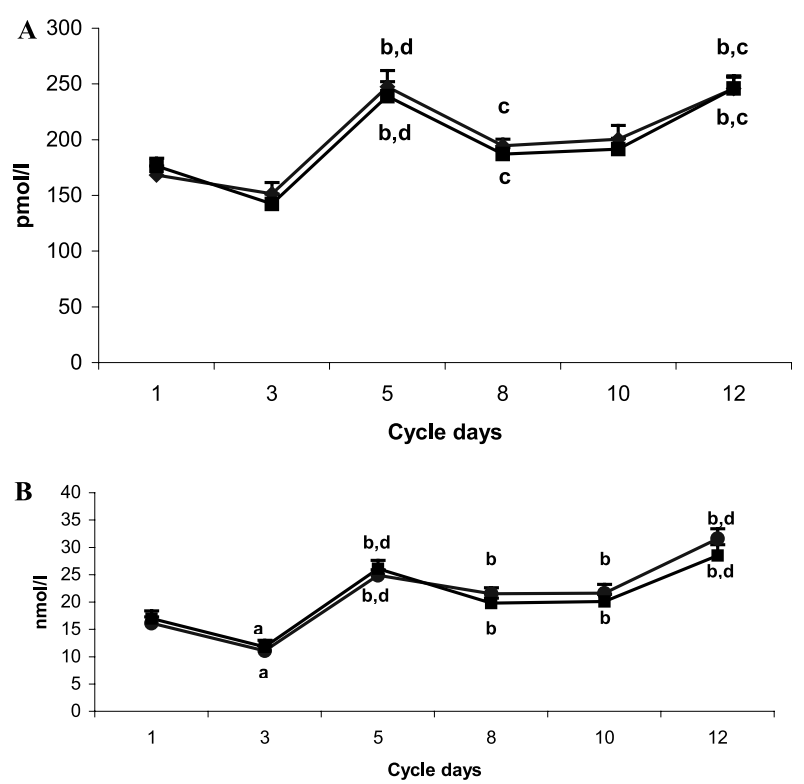

Figure 5 Changes in peripheral plasma estradiol (A) and progesterone (B) concentration in relation to endometrial receptivity in guinea pigs treated with vehicle $(\bullet)$ or ormeloxifene (a) on days $0-4$ of the estrous cycle. Note high plasma estradiol and progesterone concentration on day 5 of the cycle and lack of any effect of ormeloxifene pretreatment. ${ }^{\mathrm{a}} P<0 \cdot 05,{ }^{\mathrm{b}} P<0 \cdot 01$, vs corresponding day 1 group; ${ }^{\mathrm{c}} P<0 \cdot 05,{ }^{\mathrm{d}} P<0 \cdot 01$, vs corresponding preceding day of cycle. All other relevant comparisons were statistically not significant.

Peripheral plasma estradiol and progesterone concentration Maximum plasma estradiol concentration was observed on the day of maximal endometrial receptivity $(P<0 \cdot 01$, vs days 1 or 3 ; Fig. $5 \mathrm{~A})$. A transient but statistically significant $(P<0 \cdot 05$, vs day 5$)$ decrease was observed on days 8 and 10 , followed by an increase on day $12(P<0 \cdot 05$, vs days 8 or 10$)$ to reach almost the same levels as observed on day 5 of the cycle. In comparison, the high level of plasma progesterone observed on day 5 of the estrous cycle $(P<0 \cdot 01$, vs days 1 or 3 ; Fig. $5 \mathrm{~B})$ was maintained until day 10. This was followed by a further increase to reach peak levels on day 12 of the cycle $(P<0 \cdot 01$, vs days 5,8 or 10$)$. Ormeloxifene pretreatment did not affect ovarian function in the guinea pig and peripheral plasma estradiol and progesterone concentrations on the day of maximal endometrial receptivity and at various time intervals post-traumatization were similar to those of controls.

\section{Estrogen antagonistic activity of ormeloxifene}

In ovariectomized adult guinea pigs, estradiol-17 $\beta$ treatment for 1,2 or 3 days induced a marked increase in uterine weight (Fig. 6A) as well as ODC activity (Fig. 6B), the increase in enzyme activity being generally more in the AM than the mesometrial segment of the uterus.

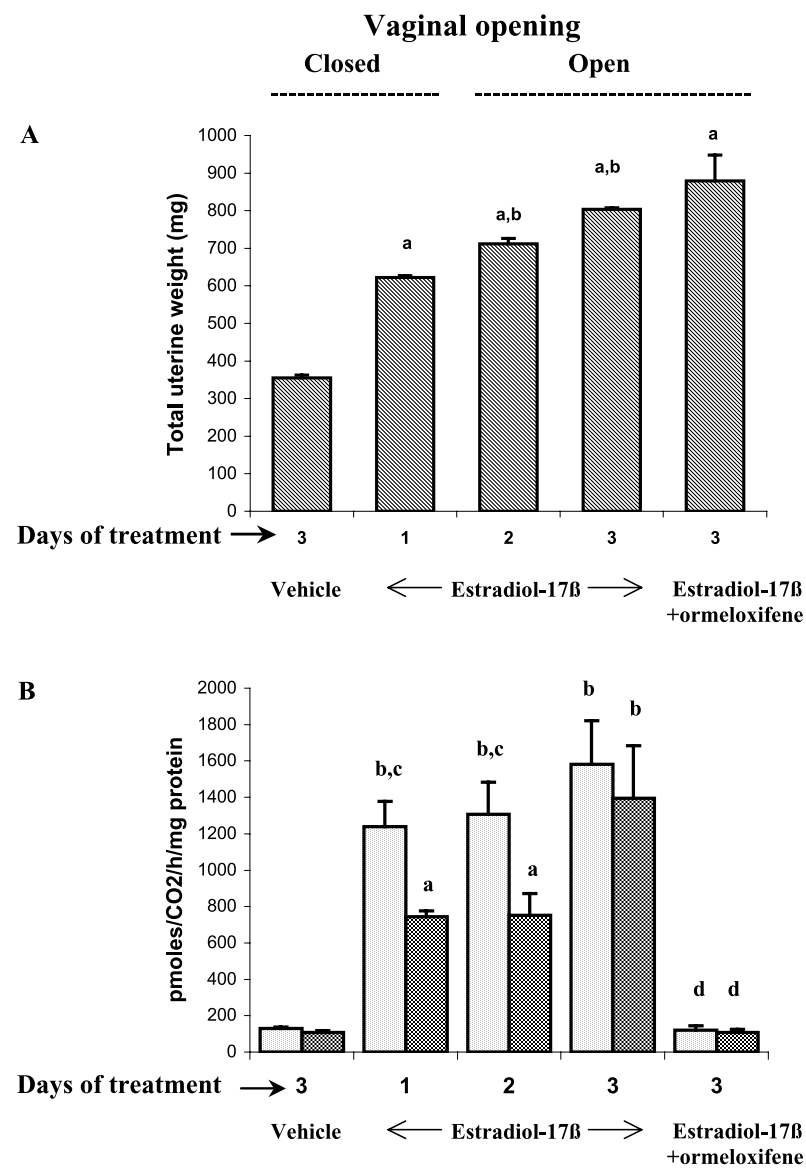

Figure 6 Estrogen antagonistic activity of ormeloxifene in bilaterally ovariectomized adult guinea pigs. Note marked increase in uterine weight (A) as well as ODC activity (B) in females receiving estradiol- $17 \beta$ for 1,2 or 3 days. Increase in enzyme activity was generally more in the AM (light bars) than the mesometrial (dark bars) segment of the uterus. Animals receiving estradiol for 2 or 3 days, in addition, exhibited premature opening of the vagina. Ormeloxifene administered concurrently with estradiol-17 $\beta$ for 3 days markedly inhibited estradiol-induced ODC activity in the two segments. (A) ${ }^{a} P<0 \cdot 01$, vs vehicle control group, ${ }^{\mathrm{b}} \mathrm{P}<0 \cdot 01$, vs preceding treatment group. (B) ${ }^{\mathrm{a}} P<0 \cdot 05,{ }^{\mathrm{b}} P<0 \cdot 01$, vs corresponding vehicle control group, ${ }^{\mathrm{C}} P<0 \cdot 05$, vs corresponding mesometrial segment, ${ }^{\mathrm{d}} P<0 \cdot 01$, vs corresponding estradiol per se treated control group. All other relevant comparisons were statistically not significant.

Animals receiving estradiol for 2 or 3 days, in addition, exhibited premature opening of the vagina. Ormeloxifene administered concurrently with estradiol-17 $\beta$ for 3 days caused marked inhibition in ODC activity in AM and mesometrial segments of the uterus; the decrease being similar (AM: 92.2\%; mesometrial: 92.3\%) in the two segments when compared with the corresponding estradiol-17 $\beta$ per se treated group. There was, however, no effect of ormeloxifene treatment on estradiol-induced uterine weight gain or premature vaginal opening (Fig. 6A). 


\section{Discussion}

The results of this study provide evidence of SOD playing an important role in protecting the guinea pig uterus against oxygen radical cytotoxicity during endometrial receptivity, a phenomenon crucial for implantation and decidualization. This is supported by inhibition in the activity of the cytosolic or the $\mathrm{Cu}, \mathrm{Zn}$ SOD and endometrial responsiveness to deciduogenic stimulus by the antiestrogen ormeloxifene. Accumulating data suggest a role of superoxide in reproductive processes involving embryonic development and implantation (Orsi et al. 2001, Carla et al. 2005). Reduced fertility has been observed in female mice lacking $\mathrm{Cu}, \mathrm{Zn}$ SOD that might result from a defect in implantation of embryos to the uterine wall or premature death of the fetuses (Ho et al. 1998, Matzuke et al. 1998). These observations get support from the reported improvement of fertility in Toki-Shakuyaku San-treated mice through removal of excess superoxide (Ota et al. 1999a). Cu,Zn SOD activity has also been reported to peak in human endometrium during the midsecretory phase of the menstrual cycle (Sugino et al. 1996), coinciding with the window for implantation of the blastocyst (Wilcox et al. 1999). In addition, a role for superoxide in infertility associated with diseases like endometriosis and adenomyosis has been suggested (Ota et al. 1999a). These observations might suggest the possibility of endometrial receptivity improvement via augmenting antioxidant defenses.

Although we did not measure the levels of superoxide radicals or $\mathrm{H}_{2} \mathrm{O}_{2}$ in this study, inhibition of SOD activity by ormeloxifene, while confirming estrogen dependency of this enzyme, might suggest its contraceptive action via a depressed antioxidant defense system and altered cellular toxicity due to increased superoxide radicals as realized by decreased activity of SOD in this species. This might be related to its estrogen antagonistic activity and/or decreased bioavailability of estradiol at the cellular level due to its increased metabolism to biologically less-active estrone via activation of estradiol-17 beta-HSD and suppression of estrone-17 beta-HSD. Reports of pronounced hypertrophy with signs of cellular degeneration in the uterine luminal epithelium and inhibition of uterine gland genesis in rats treated with tamoxifen, a triphenylethylene antiestrogen, which like ormeloxifene possesses inherent weak estrogen agonistic activity, are available (Branham et al. 1985, Singh 2001). Evidence also exists that exposure of the ER-containing rat pituitary $\mathrm{GH}_{3}$ cell line to the antiestrogen ZM182780 greatly increases its receptivity to oxidants generated by blocking cellular antioxidant pathways and from exogenous administration of $\mathrm{H}_{2} \mathrm{O}_{2}$ (Newton et al. 1999). A decrease in Cu,Zn SOD expression and activity has been observed in human endometrial stromal cells in vitro following withdrawal of estrogen and progesterone leading to generation of ROS, which might not only cause tissue damage but also produce substances such as prostaglandin $\mathrm{F}_{2 \alpha}$ or matrix metalloproteinases, suggesting a role of SOD in maintenance of cell function (Sugino et al. 2002, 2004).

There was also an increase in peroxidase activity primarily in the AM segment of the uterus in vehicle control females on the day of maximal endometrial receptivity. Histochemically, too, intense peroxidase staining was evident along the AM side of the uterus. This is in accord with the reported increase in peroxidase activity towards the antimesometrial-mesometrial junction and the mesometrial pole where the blood supply enters the uterus (McMaster et al. 1992). This, together with inhibition in peroxidase activity in only the AM segment, on the day of maximal endometrial receptivity in guinea pigs pretreated with ormeloxifene, suggests a supplementary role of peroxidase in protecting the uterus against oxidative damage during this crucial phenomenon in implantation. Pertinently, while ormeloxifene caused marked inhibition in SOD activity on the day of maximal endometrial receptivity, with levels reaching almost 56\% lower than the corresponding vehicle control group, peroxidase activity exhibited only slight (24\%), although statistically significant, inhibition in the AM side of the uterus, i.e. the side which is first to acquire receptivity and where implantation initiates in most mammals including the guinea pig (Blandau 1971).

High, although unaltered levels of CAT, GR and G-6-PDH, which remained almost unaltered after ormeloxifene treatment, were observed throughout the prereceptivity period in this study. This might suggest that the activity of these enzymes is not estrogen dependent in this species, although their high levels might be important for disposal of free radicals (Singh et al. 1996a, Kaneko et al. 2001), and maintenance of redox status of the cells. Pertinently, reports of selective action of estrogen on SOD expression, without altering the activity of other antioxidant enzymes such as CAT and glutathione peroxidase are available (Strehlow et al. 2003).

The findings of this study also provide evidence of marked inhibition in endometrial receptivity, induced decidualization and associated increase in ODC activity following treatment with ormeloxifene. Ormeloxifene is a non-steroidal SERM known to inhibit implantation by inhibition of endometrial receptivity without markedly affecting the hypothalamo-pituitary-ovarian axis, ovarian steroidogenesis or development or viability of preimplantation embryos at the contraceptive dose in the rat (Singh 2001). This is believed to be via inhibition of the action, and not synthesis, of nidatory estrogen, responsible for induction of endometrial receptivity, at the receptor level (Singh 2001) in species like the rat that exhibit facultative delay of implantation (Finn \& Porter 1975). ODC is a rate-limiting enzyme in the synthesis of polyamines (Webster et al. 1984), which are believed to be functionally involved in protein synthesis (Tabor \& Tabor 1984) and DNA replication (Geiger \& Morris 1978). 
Their depletion inhibits growth and cell division (Manni \& Wright 1984). Increased ODC activity has been demonstrated during the pre-replication period to ready the cell for growth and division (Sunkara et al. 1979). In the present study, we have observed significantly higher ODC activity in the AM segment, which is the first to acquire receptivity (Weitlauf 1994) than in the mesometrial segment of the uterus. The observed increase in ODC activity, with increasing decidualization in the present study, confirms its significant role in growing decidual tissue (Fozard 1987). The inhibition of ODC activity by ormeloxifene pretreatment confirms the antiestrogenic action of this SERM at the uterine level. It may be pointed out that stimulation in ODC activity by estrogen and its inhibition by antiestrogens in the rat uterus has been reported (Rorke et al. 1984, Barkai et al. 1992).

Triphenylethylene antiestrogens are well known to increase the concentration and retention of the nuclear ER pool (Ferguson \& Katzenellenbogen 1977, Sreenivasulu et al. 1992). We have also observed a marked depletion in cytoplasmic ER and an increase in nuclear ER content in AM and mesometrial segments of uteri of guinea pigs on day 5 after ormeloxifene treatment (Makker 1995). According to Clark et al. (1973, 1974), the estrogen antagonistic property of an antiestrogen lies in its inability to stimulate receptor synthesis and replenishment. Jordan et al. (1978) and Jordan \& Naylor (1979) have postulated that prolonged depletion of the uterine cytoplasmic ER concentration in antiestrogen-treated rats is due to its long biological half-life. According to these investigators, fresh ER may be synthesized in the presence of these antiestrogens but they are regularly translocated to the nucleus, leaving the cytoplasmic receptor pool depleted, thus making the tissue refractory to further estrogen action. A similar explanation may be put forward for depletion of cytoplasmic ER after ormeloxifene treatment, which may be responsible for loss of endometrial receptivity (Makker 1995). There was, however, no effect of ormeloxifene on nuclear or cytoplasmic progesterone receptor concentration. This, together with lack of effect on peripheral plasma progesterone concentration indicating unaffected corpus luteum function, confirms a lack of an inherent progesterone antagonistic effect of ormeloxifene (Singh 2001) and provides evidence that endometrial maturation can be altered without affecting ovarian function. The precise mechanism or significance of antagonism of progesterone action by ormeloxifene observed in certain bioassays vis-à-vis its antideciduogenic/anti-implantation action remains enigmatic and has been discussed in detail (Singh 2001).

The guinea pig is a unique laboratory rodent species with similarities to humans in the presence of interstitial implantation and a functional luteal phase (Motta \& Hutchinson 1991, Lee \& DeMayo 2004). Occurrence of an 'implantation window' in the guinea pig, like that in lower rodent species, is well established (Mitchell \& Garris 1978) and its occurrence in primates, including humans, is also suggested (Martel et al. 1987). However, the precise hormonal requirement for induction of endometrial receptivity in the guinea pig or any of the higher mammalian species with a functional luteal phase is still not clearly understood. We have demonstrated high plasma concentrations of estradiol and progesterone and their receptors in nuclear and cytosolic fractions of the uterus on the day of maximal endometrial receptivity and their marked increase following induced decidualization, confirming possible roles of both estradiol and progesterone in induction of endometrial receptivity and decidualization in this species (Makker et al. 1994). This, together with decidualization- and estrogen-induced increases in ODC activity in the present study, further substantiates a possible role of estrogen in this crucial phenomenon in implantation in the guinea pig and probably also in species in which implantation ensues with progesterone alone following ovariectomy immediately post-mating. Incidentally, species such as hamster (Joshi \& Labhsetwar 1972) and guinea pig (O'Grady \& Bell 1977, Mitchell \& Garris 1978), which do not appear to require nidatory estrogen for implantation, have been reported to have much higher circulating levels of estradiol than species like the rat where nidatory estrogen is obligatory for induction of endometrial receptivity and implantation (Singh \& Kamboj 1992).

During normal implantation, uterine luminal closure and apposition of the blastocyst trophoblast with the uterine luminal epithelium is brought about by pinocytosis/endocytosis of fluid and macromolecules from the uterine lumen (Singh et al. 1996a,b). We have observed marked distention of the uterine lumen in ormeloxifene pretreated guinea pigs on the day of maximal endometrial receptivity (i.e. day 5 of the cycle). This coincides with the time of presence of viable blastocysts in utero (Singh et al. 1990), which convey deciduogenic signal(s) necessary for implantation and maternal recognition of pregnancy. Interestingly, a distended uterine lumen was evident even until day 12 of the cycle in ormeloxifene pretreated females, confirming inhibition of pinocytosis/endocytosis, uterine luminal closure and apposition of blastocyst trophoblast with the uterine luminal epithelium by this antiestrogen (Singh et al. 1996a,b).

Ormeloxifene has been reported to induce a uterotrophic response in rats and rhesus monkeys (Singh 2001) and an increase in luminal epithelial cell height in rats (Arshad et al. 2004). While increase in uterine luminal epithelial cell height has also been observed in the present study, there was no apparent effect of ormeloxifene pretreatment on endometrial thickness in normally cycling guinea pigs in the present study.

In conclusion, results of this study provide evidence of SOD playing an important role, with peroxidase having a 
supplementary role, in the first line of defense against superoxide anion radicals during the period of maximal endometrial receptivity in the guinea pig and suggest the possibility of endometrial receptivity improvement via augmenting antioxidant defenses. Inhibition of endometrial receptivity and decidualization by ormeloxifene administered during the pre-receptive phase appears to be due to a reduced antioxidant defense system via dysregulation of redox-sensitive signaling and might contribute to the contraceptive action of ormeloxifene. Reduced estradiol bioavailability at the cellular level and the activity of ODC by ormeloxifene confirm our previous findings on the role of estrogen in implantation in this species (Makker et al. 1994, Makker 1995).

\section{Acknowledgements}

The authors thank Miss Mohini Chhabra for technical assistance, Dr S C Moitra for electron microscopy, Mr P S N Murthy for histomorphometry, Dr S Ray for supply of ormeloxifene, Dr Mukesh Srivastava for statistical analysis and Mr B P Mishra and Mr Jagdish Prasad for handling of animals. Dr F W Bansode was responsible for histochemistry. This is Central Drug Research Institute communication no. 6596.

\section{Funding}

This study received financial support from the Ministry of Health and Family Welfare, Government of India. One of us (A M) thanks the CSIR, New Delhi for the award of a Research Fellowship. The authors declare that there is no conflict of interest that would prejudice the impartiality of this scientific work.

\section{References}

Agarwal P \& Laloraya MM 1979 Ascorbate and peroxidase changes during pregnancy in albino rat and Swiss mouse. American Journal of Physiology 236 E386-E390.

Arshad M, Sengupta S, Sharma S, Ghosh R, Sawlani V \& Singh MM 2004 In vitro anti-resorptive activity and prevention of ovariectomy-induced osteoporosis in female Sprague-Dawley rats by ormeloxifene, a selective estrogen receptor modulator. Journal of Steroid Biochemistry and Molecular Biology 91 67-78.

Barkai U \& Kraicer PF 1978 Definition of period of induction of deciduoma in the rat using ornithine decarboxylase as a marker of growth onset. International Journal of Fertility 23 106-111.

Barkai U, Kidron T \& Kraicer PF 1992 Inhibition of decidual induction in rats by clomiphene and tamoxifen. Biology of Reproduction 46 733-739

Blandau RJ 1971 Implantation. In Proceedings of the Symposium on the Use of Non-Human Primates for Research Problems in Human Reproduction, 13-17 December 1971, Sukhumi, USSR, pp 69-92. Eds E Diczfalusy \& CC Standlet. Copenhagen: Bogtrykkeriet Forum for WHO Research Training Centre on Human Reproduction, Karolinska Institutet, Stockholm.
Branham WS, Sheehan DM, Zehr DR, Medlock KL, Nelson CJ \& Ridlon E 1985 Inhibition of rat uterine gland genesis by tamoxifen. Endocrinology 117 2238-2248.

Carla B, Barbara P, Laura L, Sara F \& Fortunato V 2005 The role and modulation of the oxidative balance of pregnancy. Current Pharmaceutical Design 11 2075-2089.

Chen TJ, Hwang TC, Huang CC, Jow GM \& Yu JYL 1989 Deciduomal estrogen and progesterone receptors in unilateral pregnant hamsters. Endocrinology 125 302-307.

Clark JH, Anderson JN \& Peck EJ Jr 1973 Estrogen receptor-antiestrogen complex: atypical binding by uterine nuclei and effects on uterine growth. Steroids 22 707-718.

Clark JH, Peck EJ \& Anderson JN 1974 Estrogen receptors and antagonism of steroid hormone action. Nature 251 446-448.

Droge W 2002 Free radicals in the physiological control of cell function. Physiological Reviews 82 47-95.

Ferguson ER \& Katzenellenbogen BS 1977 A comparative study of antiestrogen action: temporal patterns of antagonism of estrogen stimulated uterine growth and effects on estrogen receptor levels Endocrinology 100 1242-1250.

Finn CA \& Porter DG 1975 Implantation of ova. In The Uterus, pp 57-73 and 86-95. Eds CA Finn \& DG Porter. London: Elek Science.

Fozard JR 1987 The contragestational effects of ornithine decarboxylase inhibition. In Inhibition of Polyamine Metabolism Biological Significance and Basis for New Therapies, pp 187-202. Eds PP McCann, AE Pegg \& A Sjoerdsma. New York: Academic Press Inc.

Fridovich I 1978 The biology of oxygen radicals. Science 201 875-880.

Garris DR 1984 Decidual tissue growth and regression in the guinea pig: Regulation by uterine blood flow and relation to circulating progesterone concentrations. Endocrinology 114 1599-1604.

Geiger LE \& Morris DR 1978 Polyamine deficiency reduces the rate of DNA replication fork movement in Escherichia coli. Nature $\mathbf{2 7 2}$ 730-732.

Guidice LC 1999 Potential biochemical markers of endometrial receptivity in clinical practice. Human Reproduction 14 (Suppl 2) 3-16.

Ho YS, Gargano M, Cao J, Bronson RT, Heimler I \& Hutz RJ 1998 Reduced fertility in female mice lacking copper zinc superoxide dismutase. Journal of Biological Chemistry 273 7765-7769.

Jauniaux E, Watson AL, Hempstock J, Bao Y, Skepper JN \& Burton GJ 2000 Onset of maternal arterial blood flow and placental oxidative stress, a possible factor in human early pregnancy failure. American Journal of Pathology 157 2111-2122.

Jordan VC \& Naylor KE 1979 The binding of ${ }^{3} \mathrm{H}$-oestradiol in the immature rat uterus during the sequential administration of antiestrogens. British Journal of Pharmacology 65 168-173.

Jordan VC, Rowsby L, Dix CJ \& Prestwich G 1978 Dose-related effects of non steroidal antiestrogens and oestrogens on the measurement of cytoplasmic oestrogen receptors in the rat and mouse uterus. Journal of Endocrinology 78 71-81.

Joshi HS \& Labhsetwar AP 1972 The pattern of ovarian secretion of oestradiol and oestrone during pregnancy and the post-partum period in the hamster. Journal of Reproduction and Fertility $\mathbf{3 1}$ 299-302.

Kaneko T, Iuchi Y, Kawachiya S, Fujji T, Saito H, Kurachi H \& Fujii J 2001 Alteration of glutathione reductase expression in the female reproductive organs during the estrous cycle. Biology of Reproduction 65 1410-1416.

Kaye AM, Icekson I \& Linder HR 1971 Stimulation by estrogens of ornithine and S-adenosylmethionine decarboxylase in the immature rat uterus. Biochimica et Biophysica Acta 252 150-159.

King WJ, Allen TC \& DeSombre ER 1981 Localization of uterine peroxidase activity in oestrogen treated rats. Biology of Reproduction 25 859-870. 
Laloraya M, Kumar P \& Laloraya MM 1989 A possible role of superoxide anion radical in the process of blastocyst implantation in mice. Biochemical and Biophysical Research Communications 161 $762-770$.

Lee KY \& DeMayo FJ 2004 Animal models in implantation. Reproduction 128 679-695.

Lowry OH, Rosebrough NJ, Farr AL \& Randall RJ 1951 Protein measurement with the Folin phenol reagent. Journal of Biological Chemistry 193 265-271.

Lyttle RC \& DeSombre ER 1977 Uterine peroxidase as a marker for estrogen action. PNAS $\mathbf{7 4}$ 3162-3166.

Makker A 1995 Chemical and biochemical studies in guinea pigs on the effect of centchroman, an antipregnancy compound. $P h D$ Thesis. Agra University, Agra, India.

Makker A \& Singh MM 1992 Hormonal requirements for uterine decidualization and implantation: effect of hormone antagonists and agonists. Central Drug Research Institute, Lucknow, India, Annual Report, p 6.

Makker A, Singh MM, Chowdhury SR, Moitra SC \& Kamboj VP 1994 Uterine estradiol and progesterone receptor concentration in relation to circulating hormone levels and histoarchitecture during high endometrial receptivity and induced decidualization in guinea pigs. Journal of Steroid Biochemistry and Molecular Biology 48 535-543.

Manni A \& Wright C 1984 Reversal of the antiproliferative effect of the antiestrogen tamoxifen by polyamines in breast cancer cells. Endocrinology 114 836-839.

Martel D, Frydman R, Glissant M, Maggioni C, Roche D \& Psychoyos A 1987 Scanning electron microscopy of post-ovulatory human endometrium in spontaneous cycles and in cycles stimulated by hormone treatment. Journal of Endocrinology 114 319-324.

Matzuke MM, Dionne L, Guo Q, Rajendra Kumar T \& Lebovitz RM 1998 Ovarian function in superoxide dismutase 1 and 2 knockout mice. Endocrinology 139 4008-4011.

McMaster MT, Newton RC, Dey SK \& Andrews GK 1992 Activation and distribution of inflammatory cells in the mouse uterus during the pre-implantation period. Journal of Immunology 148 1699-1705.

Mehrotra SN \& Finn CA 1974 Cell proliferation in the uterus of the guinea pig. Journal of Reproduction and Fertility 37 405-409.

Mitchell JA \& Garris DR 1978 Deciduoma formation in response to uterine trauma in the guinea pig. Biology of Reproduction 19 $1135-1141$

Motta CM \& Hutchinson JSM 1991 Effects of clomiphene citrate on early pregnancy in guinea pig. Journal of Reproduction and Fertility 92 65-73.

Narimoto K, Noda Y, Shiotani M, Tokura T, Goto Y, Takakura K, Mori T, Fujimoto K \& Ogawa K 1990 Immunohistochemical assessment of superoxide dismutase expression in the human endometrium throughout the menstrual cycle. Acta Histochemica et Cytochemica 23 487-498.

Newton CJ, Drummond N, Burgoyne CH, Speirs V, Stalla GK \& Atkin SL 1999 Functional inactivation of the oestrogen receptor by the antioestrogen, ZM 182780, sensitizes tumor cells to reactive oxygen species. Journal of Endocrinology 161 199-210.

O'Grady JE \& Bell SC 1977 The role of endometrium in blastocyst implantation. In Development in Mammals, vol 1, pp 165-244. Ed $\mathrm{MH}$ Johnson. Amsterdam: Elsevier.

Orsi NM \& Leese HJ 2001 Protection against reactive oxygen species during mouse pre-implantation embryo development: role of EDTA, oxygen tension, catalase, superoxide dismutase and pyruvate. Molecular Reproduction and Development 59 44-53.

Ota H, Igarashi S, Hatazawa J \& Toshinobu T 1999a Immunohistochemical assessment of superoxide dismutase expression in the endometrium in endometriosis and adenomyosis. Fertility and Sterility 72 129-134.

Ota H, Igarashi S \& Tanaka T 19996 Improved fertility through superoxide removal by Toki-Shakuyaku-San in mice - a preliminary study. Reproduction, Fertility, and Development 11 451-455.
Racker E 1955 Glutathione reductase from Baker's yeast Beef liver. Journal of Biological Chemistry 217 855-865.

Rorke EA, Kendra KL \& Katzenellenbogen BS 1984 Relationships among uterine growth, ornithine decarboxylase activity and polyamine levels: studies with estradiol and antiestrogens. Molecular and Cellular Endocrinology 38 31-38.

Saeed A, Sharma AP, Durani N, Jain R, Durani S \& Kapil RS 1990 Structure-activity relationship of antiestrogens: studies on 2,3-diaryl-1-benzopyrans. Journal of Medicinal Chemistry 33 3210-3216.

Schublinsky A, Marin C \& Gurpide E 1976 Localization of estradiol 17 beta-dehydrogenase in human endometrium. Journal of Steroid Biochemistry 7 745-747.

Singh MM 2001 Centchroman a selective estrogen receptor modulator, as a contraceptive and for the management of hormone-related clinical disorders. Medicinal Research Reviews 21 302-347.

Singh MM \& Kamboj VP 1992 Fetal resorption in rats treated with an antiestrogen in relation to luteal phase nidatory estrogen secretion. Acta Endocrinologica 126 444-450.

Singh G, Singh MM, Moitra SC, Elger W, Kalra V, Upadhyay SN, Chowdhury SR \& Kamboj VP 1988 Luteolytic action of two antiprogestational agents (RU-38486 and ZK-98734) in the rat. Journal of Reproduction and Fertility 83 73-83.

Singh MM, Hasan SH \& Elger W 1990 Action of antiprogestin ZK 98299 on pre-implantation embryonic development and implantation in guinea pig. In International Conference on Frontiers in Reproductive Physiology and 3rd Annual Meeting of the Indian Society for Study of Reproduction and Fertility, 8-10 November, New Delhi.

Singh MM, Trivedi RN, Chauhan SC, Srivastava VML \& Kamboj VP 1996a Uterine estradiol and progesterone receptor concentration, activities of certain antioxidant enzymes and dehydrogenases and histoarchitecture in relation to time of secretion of nidatory estrogen and high endometrial sensitivity in rat. Journal of Steroid Biochemistry and Molecular Biology $\mathbf{5 9}$ $215-224$.

Singh MM, Chauhan SC, Trivedi RN, Moitra SC \& Kamboj VP $1996 b$ Correlation of pinopod development on uterine luminal epithelial surface with hormonal events and endometrial receptivity in rat. European Journal of Endocrinology 135 107-117.

Sreenivasulu S, Dwivedi I, Singh MM, Setty BS \& Kamboj VP 1992 CDRI-85/287: studies on competition to estrogen binding sites in the immature rat uterus. Indian Journal of Experimental Biology $\mathbf{3 0}$ 1115-1117.

Strehlow K, Rotter S, Wassmann S, Adam O, Grohe C, Laufs K, Bohm M \& Nickenig G 2003 Modulation of antioxidant enzyme expression and function by estrogen. Circulation Research $\mathbf{9 3}$ $170-177$.

Sugino N, Shimamura K, Takiguchi, S, Tamura H, Ono M, Nakata M, Nakamura Y, Ogino K, Uda T \& Kato H 1996 Change in activity of superoxide dismutase in the human endometrium throughout the menstrual cycle and in early pregnancy. Human Reproduction 11 1073-1078.

Sugino N, Karube-Harada A, Kashida S, Takiguchi S \& Kato H 2001 Reactive oxygen species stimulate prostaglandin $\mathrm{F} 2 \alpha$ production in human endometrial stromal cells in vitro. Human Reproduction $\mathbf{1 6}$ 1797-1801.

Sugino N, Karube A, Kashida S, Takiguchi S \& Kato H 2002 Differential regulation of copper-zinc superoxide dismutase and manganese superoxide dismutase by progesterone withdrawal in human endometrial stromal cells. Human Reproduction 8 68-74.

Sugino N, Karuba-Harada A, Taketani T, Sakata A \& Nakamura Y 2004 Withdrawal of ovarian steroids stimulates prostaglandin F2 $\alpha$ production through nuclear factor- $\mathrm{\kappa B}$ activation via oxygen radicals in human endometrial stromal cells: potential relevance to menstruation. Journal of Reproduction and Development $\mathbf{5 0}$ $215-225$. 
Sunkara PS, Pargac MB, Nishioka K \& Rao PN 1979 Differential effects of inhibition of polyamine biosynthesis on cell cycle traverse and structure of the prematurely condensed chromosomes of normal and transformed cells. Journal of Cellular Physiology $\mathbf{9 8}$ 451-457.

Tabor CW \& Tabor H 1984 Polyamines. Annual Review of Biochemistry 53 749-790.

Takiguchi S, Sugino N, Kashida S, Yamagata Y, Nakamura Y \& Kato H 2000 Rescue of the corpus luteum and an increase in luteal superoxide dismutase expression induced by placental luteotrophins in the rat: action of testosterone without conversion to estrogen. Biology of Reproduction 62 398-403.
Webster RA, Zalouder CJ \& Inman BC 1984 Stimulation of uterine ornithine decarboxylase in organ culture by decreasing osmolality: possible relation to in vivo mechanisms. Life Sciences 34 1281-1286.

Weitlauf HM 1994 Biology of implantation. In The Physiology of Reproduction, ch 7, pp 391-440. Eds E Knobil \& JD Neill. New York: Raven Press.

Wilcox AJ, Baird DD \& Weinberg CR 1999 Time of implantation of the conceptus and loss of pregnancy. New England Journal of Medicine 340 1796-1799.

Received 14 October 2005

Accepted 20 October 2005 